\title{
PCR EXPRESSION ANALYSIS OF THE ESTROGEN- INDUCIBLE GENE BCEI IN GASTROINTESTINAL AND OTHER HUMAN TUMORS
}

\author{
IRIS WUNDRACK*, ROMAN MÜLLENBACH*. CORNELIUS WELTER ${ }^{\$}$. GERHARD SEITZ \\ NIKOLAUS BLIN* \\ Dir: of Molecular Genetics, University of Tübingen. \\ \$ Dept. of Human Genetics, Saar University, Homburg/Sarar \\ s Dept. of Patholog!: Bamberg Hospital. Bamberg. German!
}

\begin{abstract}
SUMMARY
A polymerase chain reaction (PCR) assay was developed to test for tumor cell specific expression of the BCEI gene. This new marker gene, reported at first for human breast cancer, was found specifically active in various gastrointestinal carcinomas by previously applying immunohistochemistry and RNA (Northern blot) analysis. Presently, by using reverse transcription-PCR analysis, a series of primary tumor tissues and established tumor cell lines were tested for BCEI transcription. This approach was compared to immunostaining achieved by an antibody directed against the BCEI gene's product. The result demonstrate the superior sensitivity of PCR by indicating the gene's expression in cases where immunohistochemical testing remained negative.
\end{abstract}

KIYY Words RT-PCR BCEI/pS2 Gene regulation Hormone induction Cell lines

\section{INTRODUCTION}

In many regulatory proteins, cysteine-rich regions responsible for protein-protein interaction are present. Within the last few years a new cysteine-rich structure, known as either the trefoil motif or P-domain, has been described (Thim 1989). The P-domains are ca. 50 amino acid residues in length; the 6 cysteine residues form 3 intramolecular disulfide bridges and hence 3 loops which are responsible for the structure's resistance against proteolytic degradation. P-domains were discovered in frog mucins and porcine, murine and human peptides from the gastrointestinal tract (Hoffmann \& Hauser 1993). All known P-domain-containing peptides display very distinctive expression patterns in tissues of normal individuals. Their precise physiological role however is not yet fully understood.

Pathological expression of human P-domain peptides has been observed in various tissues. One such peptide (originally termed pS2 and later BCEI = breast cancer, estrogen induced) was shown to be inducible by estrogen in breast tissue and consequently found to be of prognostic value in breast cancer of female patients (Rio \& Chambon 1990). However, it had no comparable significance in the male counterpart (Kardas et al., 1993). We reported BCEI's transcription in carcinomas of the pancreas, biliary tract, stomach

Correspondence to: I. Wundrack. Division of Molecular Genetics. University of Tübingen. Wilhelmstr. 27. D-72074 Tübingen, Germany. 
and colon (Welter et al., 1992, Seitz et al., 1991, Theisinger et al., 1991, Welter et al., 1994). Furthermore, we were able to show that it is only the glandular and not the squamous component of these tumors that expresses BCEI and therefore suggests BCEI to be a secreted protein (Welter et al., 1993) thus confirming previous observations (Rio \& Chambon 1990), Hoffmann \& Hauser 1993). In these studies, we and others had investigated BCEI's expression in primary tumor tissues by using transcriptional analysis (Northern blots) (Welter et al., 1992, Seitz et al., 1991, Theisinger et al., 1991, Welter et al., 1994) or immunohistochemistry (Welter et al., 1993, Luqmani et al., 1992).

For convenient screening of large sample collections and in cases of limited sample size we now have developed a reverse transcription-polymerase chain reaction (RTPCR) assay and applied this method to monitor the BCEI gene's activity in tumors and permanent cancer cell lines from the gastrointestinal tract. Such a strategy has been already successfully applied for various gene expression studies such as for leukemia specific BCR-ABL fusion mRNA and Duchenne muscular dystrophy mutations (Kawasaki et al., 1988, Roberts et al., 1990).

\section{MATERIAL AND METHODS}

\section{Tumor material}

Human tumor specimens, classified according to Lauren (as described in detail by Thesinger et cll., 1991; Luqmani et al., 1992), were dissected for histopathology. All 5 samples were stomach carcinoma of the intestinal type. Tumor tissue was frozen within 30 min of operation in liquid $\mathrm{N}_{2}$ for preparation of nucleic acids or fixed in formalin for immunohistochemical staining. The following cell lines were provided by the Tumor Library of the German Cancer Research Center, Heidelberg, or American Type Culture Collection (ATCC, Rockville, MD): MCF7, MDA/MB231 (breast carcinoma), AN-3CA (endometrium carcinoma), CX-1, HT29 (colon adenocarcinoma), Capan-2, PaCa-2, PANC-1, DANG-1, BXPC-3 (pancreatic carcinoma). They were cultivated by standard procedures according to the suppliers' information. The primary cell culture from a pancreatic carcinoma was described previously (Welter et al., 1992).

\section{$R T-P C R$}

Total cellular RNA was extracted by a standard procedure (Sambrook et al 1989). The reverse transcription-PCR steps were described previously (Roberts et al., 1990) and were applied with the following modification.

PCR primers: (PS2a) 5'-GGGGCACTTTCTGTCTTAACACCA-3' (position 142$168 \mathrm{nt}$ within the cDNA) / (PS2b) 5'-TTTGGAGCAGAGAGGAGGCAATG-3' (position 21-43 nt). Cycling conditions: $94^{\circ} \mathrm{C} 30 \mathrm{sec} ; 55^{\circ} \mathrm{C} 30 \mathrm{sec} ; 72^{\circ} \mathrm{C} 40 \mathrm{sec}, 30 \mathrm{cycles}$ using a Biometra Trio-thermoblock. RT-PCR for actin expression using a Clontech $\beta$ actin amplimer set (Clontech Inc. Palo Alto, CA, USA) was used for RNA quality control. Specificity of the BCEI PCR product was confirmed by sequencing.

\section{Immunostaining}

A monoclonal antibody (BC4) against the pS2 (BCEI) protein (supplied by CIS $\mathrm{GmbH}$, Dreicich, Germany) was applied as published previously (Rio \& Chambon 1990, Theisinger et al., 1991, Luqmani et al., 1992). Detection was obtained by the alkaline phosphatase-anti-alkaline phosphatase method (APAAP). 


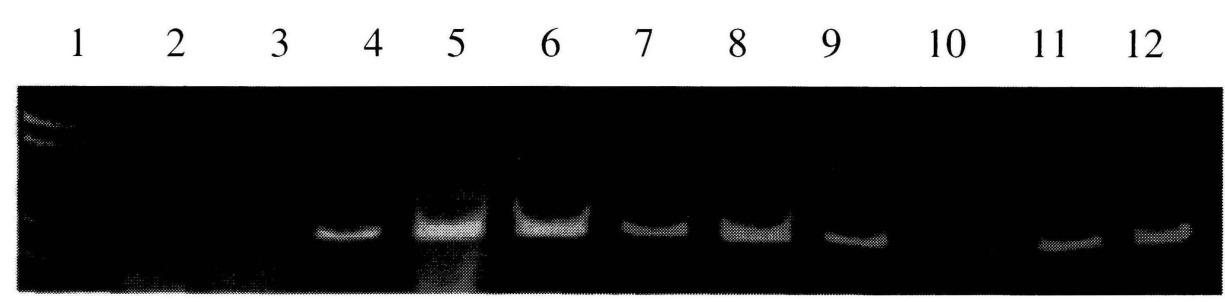

Figure 1: PCR demonstration of BCEI expression in the MCF7 breast cancer cell line and in a series of primary gastrointestinal tumors and permanent cell lines.

Lane 1: DNA size marker, 2: AN-3-CA; 3: DABG-1; 4: CAPAN-2; 5: BXPC-3; 6: T1; 7: T2; 8: T4; 9: MDA/ MB231; 10: $150 \mathrm{ng} ; 11: 500 \mathrm{ng}$ and 12:1000 ng RNA from MCF7.

\section{RESULTS}

The BCEI (pS2) gene, originally shown to be under estrogen transcriptional control and isolated from the breast cancer cell line MCF7, displays within its coding DNA sequence blocks suitable to generate primers necessary for PCR. From two, primers were synthesized and the complete RT-PCR assay was performed with mRNA from MCF7 cells.

An expected product of $150 \mathrm{bp}$ was obtained with as little as $100 \mathrm{ng}$ total RNA (corresponding to ca. $5 \mathrm{ng}$ mRNA) ascertaining the sensitivity of this approach (Fig. 1). In addition to MCF7 cells, containing estrogen receptors (leading to the beforementioned transcriptional control of $\mathrm{pS} 2$ ), we also tested an estrogen receptor-negative breast cancer cell line, MDA/MB231. A distinct $150 \mathrm{bp}$ band in the RT-PCR assay demonstrated pS2 expression in these cells lacking estrogen receptors (Fig. 1).

Our previous studies (by immunostaining and Northern blot hybridization) revealed that the BCEI gene was transcriptionally inactive in normal pancreatic cells and we noted its expression in a primary pancreatic cell culture plus in a majority $(74 \%)$ of pancreatic tumor samples. Weaker but still distinguishible immunostaining $(<5 \%$ immunopositive cells) was notable in the remaining $26 \%$ of the tumors. We decided to investigate a series of permanent cell lines established from pancreatic carcinoma. Surprisingly, none of them showed BCEI expression when tested by immunostaining. PCR analysis resulted in clearly visible signals in 3 out of 5 investigated cell lines (Table 1). We then extended the PCR study to additional carcinoma cell lines from colon and endometrium and a primary culture from a pancreatic carcinoma, the latter noted to display distinct immunostaining (Fig.2). The analysis confirmed pS2 expression in the primary culture whereas the endometrium and colon carcinoma cell lines remained negative.

In stomach carcinoma of the intestinal type, previously described to often display none or weak BCEI expression, antibody-staining indicated $~ 30 \%$ immuno-positive cells in one sample and remained very weak or negative in 4 out of 5 cases. However, residual gene expression must be present below the immunodetection level in all the cases since RT-PCR analysis showed bands of correct size (Table 1). 
Table 1. Expression of BCEI in primary tumors and permanent cell lines as determined by

\begin{tabular}{|c|c|c|c|}
\hline & Immunostaining & RT-PCR & \\
\hline \multicolumn{4}{|l|}{ breast carcinoma } \\
\hline MCF $7(E R+)$ & + & + & permanent \\
\hline MDA/MB231 (ER-) & nd & + & $\begin{array}{l}\text { cell } \\
\text { lines }\end{array}$ \\
\hline \multicolumn{4}{|l|}{ colon adenocarcinoma } \\
\hline CX-1 & - & - & \\
\hline HT29 & nd & - & \\
\hline \multicolumn{4}{|c|}{ endometrium adenocarcinoma } \\
\hline $\mathrm{AN}-3-\mathrm{CA}$ & nd & - & \\
\hline \multicolumn{4}{|l|}{ pancreas carcinoma } \\
\hline DANG-1 & - & - & \\
\hline PANC-1 & - & - & \\
\hline CAPAN-2 & - & + & \\
\hline $\mathrm{PaCa}-2$ & - & + & \\
\hline BXPC-3 & - & + & \\
\hline PCPC1 & + & + & $\begin{array}{l}\text { a pancreas } \\
\text { carcinoma primary } \\
\text { cell culture }\end{array}$ \\
\hline T1 (JW) & - & + & solid \\
\hline $\mathrm{T} 2(\mathrm{GS})$ & + & + & tumors \\
\hline T3 (KW) & - & + & \\
\hline $\mathrm{T} 4(\mathrm{St})$ & $+/-$ & + & \\
\hline $\mathrm{T} 5(\mathrm{We})$ & $+/-$ & + & \\
\hline
\end{tabular}

nd $=$ not determined

$\mathrm{ER}+=$ estrogen receptor positive cells

ER- = estrogen receptor negative cells

$+/ \quad=$ very weak immunostaining (in $<5 \%$ of the cells)

\section{DISCUSSION}

Following the milestone in genomic analysis, the application of PCR to define DNA landmarks on the physical map of the human genome (STS's), as advocated by Olson $e t$ al., (Olson et al., 1989), the PCR approach was extended to include RNA as a starting template. Synthesis of cDNA from a mRNA pool followed by PCR using selected primers allowed detection of specific fusion gene products in human leukemia (Kawasaki et al., 1988). Subsequently, this assay for the Philadelphia chromosome was shown to be very sensitive (down to mere 5 affected cells) (Morgan et al., 1989). 


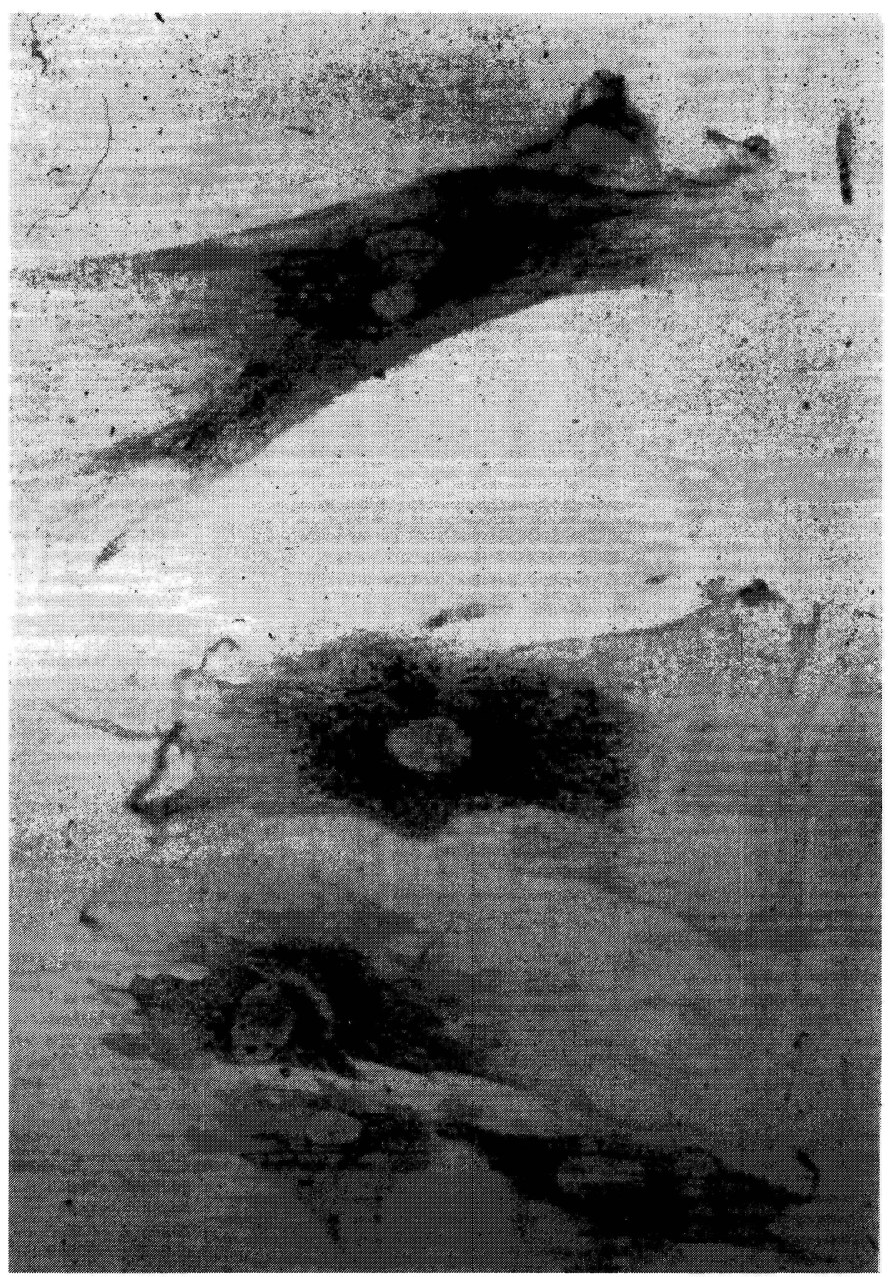

Figure 2: Immunodetection of the BCEI protein expressed in pancreatic carcinoma cells maintained as a primary cell culture.

To investigate the function and regulation of the BCEI gene we established a similar assay to conveniently screen for cell-type specific transcription. Using two apt primers, BCEI-mRNA was easily detectable in MCF7 cells, a cell line originally used for isolation of the BCEI gene. Since it is specifically expressed in various gastrointestinal tumors, its activity was presently monitored in these cells by PCR and immunostaining. To our surprise, some of the permanent cell lines established from colon, endometrium and pancreatic carcinoma showed no BCEI transcription. In 3 pancreatic cell lines, histochemical detection was not sufficiently sensitive but, by PCR, we were able to prove the gene's transcription. The same seems to be true for the gastric carcinoma samples of the intestinal type: PCR appeared superior in detecting the pS2 gene's transcription at lowest levels. 
On the basis of data accumulated from studies performed by us and other groups (reviewed in Hoffmann \& Hauser 1993) the evidence points towards BCEI's (and some other P-domain peptides') role in vivo as either a growth modulator or as a control molecule in maintaining surface integrity of mucous epithelia. Immortalized cancer cell lines obviously can loose the ability to express this gene or, at least, reduce the gene's activity below levels of immunodetection. An apt PCR assay, as demonstrated, will allow a more sensitive differentiation between complete shut-off, residual expression, and gene induction. Such determination appears essential for studies of BCEI's function, in particular in transgenic cells.

\section{ACKNOWLEDGEMENTS}

The authors are grateful to $\mathrm{G}$. Unteregger for a gift of MDA/MB cells and to $\mathrm{Ch}$. Isaacs for cultivation of the carcinoma cell lines. The project was supported by an EC travel grant, and a DFG grant (B1 166/11-1). C.W. received a Stalter Stiftung fellowship.

\section{REFERENCES}

Hoffmann, W., Hauser, F. (1993). The P-domain or trefoil motif: a role in renewal and pathology of mucous epithelia? Trends Biochem. Sci., 18, 239-243.

Kardas, I., Seitz, G., Limon, J., Niezabitowski, A., Rys, J., Theisinger, B., Welter, C., Blin, N. (1993). Retrospective analysis of prognostic significance of the estrogen-inducible $\mathrm{pS} 2$ gene in male breast carcinoma. Cancer, 72, 1652-1656.

Kawasaki, E.S., Clark, S.S., Coyne, M.Y., Smith, S.D., Champlin, R., Witte, O.N., McCormick, F.P. (1988). Diagnosis of chronic myeloid and acute lymphocytic leukemias by detection of leukemia-specific mRNA sequences amplified in vitro. Proc. Natl. Acad. Sci. USA, 85, 56985702.

Luqmani, Y.A., Ryall, G., Shousha, S., Coombes, R.C. (1992). An immuno-histochemical survey of pS2 expression in human epithelial cancers. Int. J. Cancer, 50, 302-304.

Masiakowski, P., Breathnach, R., Bloch, J., Gannon, F., Krust, A., Chambon, P. (1982). Cloning of cDNA sequences of hormone-regulated genes from the MCF-7 human breast cancer cell lines. Nucleic Acids Res.,19, 7895-7903.

Morgan, G.J., Janssen, J.W., Guo, A.P., Wiedemann, L.M., Hughes, T., Gow, J., Goldman, J.M., Bartram, C.R. (1989). Polymerase chain reaction for detection of residual leukaemia. Lancet, 4, 928-0929.

Olson, M., Hood, L., Cantor, C., Botstein, D. (1989). A common language for physical mapping of the human genome. Science, 245, 1434-1435.

Rio, M.C., Chambon, P. (1990). The pS2 gene, mRNA and protein. Cancer Cells, 2, 269-274.

Roberts, R., Bentley, D., Barby, T., Manners, E., Bobrow, M. (1990). Direct diagnosis of carriers of DMD by amplification of lymphocyte RNA. Lancet, 336, 1523-1526.

Sambrook, J., Fritsch, E., Maniatis, T. (1989). Molecular cloning. Cold Spring Harbor Laboratory Press

Seitz, G., Theisinger, B., Tomasetto, C., Rio, M.C., Chambon, P., Blin, N., Welter, C. (1991). Breast cancer-associated protein $\mathrm{pS} 2$ expression in tumors of biliary tract. Am.J. Gastroenterol., 86, 1491-1494.

Theisinger, B, Welter, C, Seitz, G, Rio, MC, Lathe, R, Chambon, P, Blin, N.(1991). Expression of the breast cancer associated gene $\mathrm{pS} 2$ and the pancreatic spasmolytic polypeptide gene (hSP) in diffuse type of stomach carcinoma. Eur. J. Cancer, 27, 77O-773.

Thim, L. (1989). A new family of growth factor-like peptides. FEBS Lett., 250, 85-90. 
Welter, C., Seitz, G., Blin, N. (1993). Expression of the breast cancer-associated protein pS2 in adenosquamous carcinomas of the gastrointestinal tract. Acta Oncol., 32, 315-317

Welter, C., Theisinger, B., Rio, M.C., Seitz, G., Schüder, G.., Blin, N. (1994). Expression pattern of breast cancer associated protein pS2/BCEI in colorectal tumors. Int. J. Cancer, 56, 52-56

Welter, C., Theisinger, B., Seitz, G., Tomasetto, C., Rio, M.C., Chambon, P., Blin, N. (1992). Association of the human spasmolytic polypeptide and an estrogen-induced breast cancer protein (pS2) with human pancreatic carcinoma. Lab. Invest., 66, 187-192. 


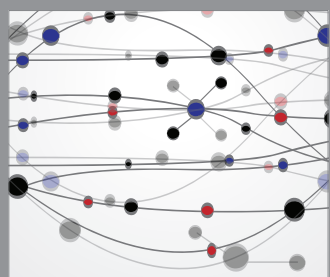

The Scientific World Journal
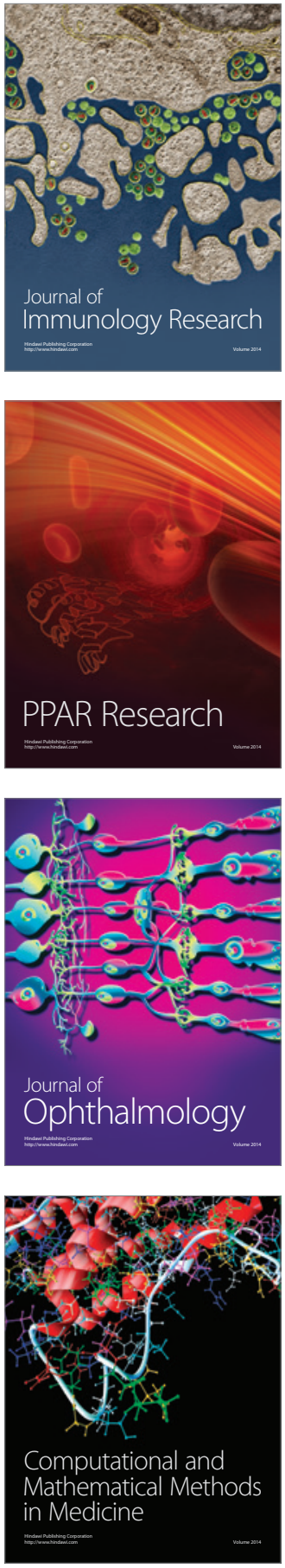

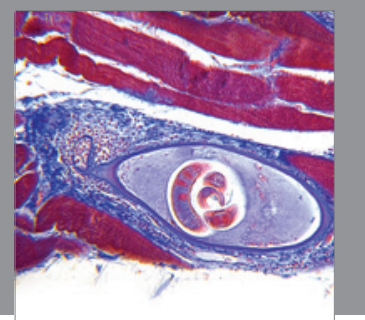

Gastroenterology

Research and Practice
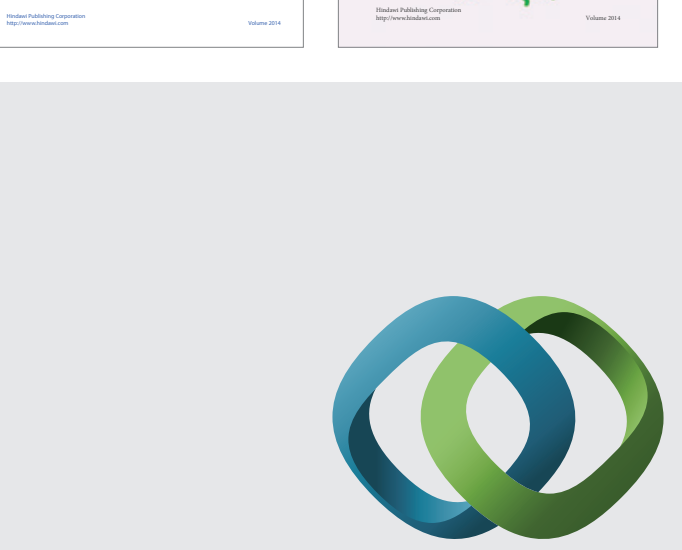

\section{Hindawi}

Submit your manuscripts at

http://www.hindawi.com
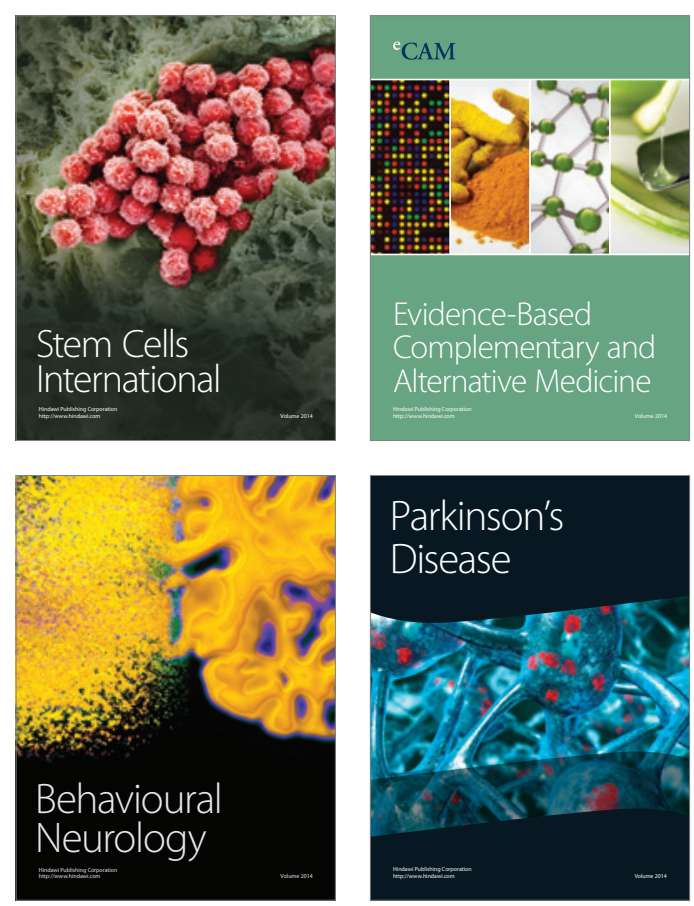

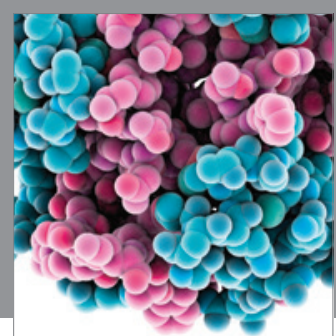

Journal of
Diabetes Research

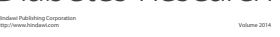

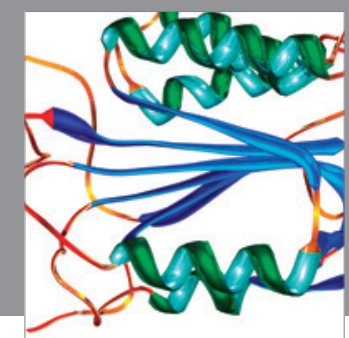

Disease Markers
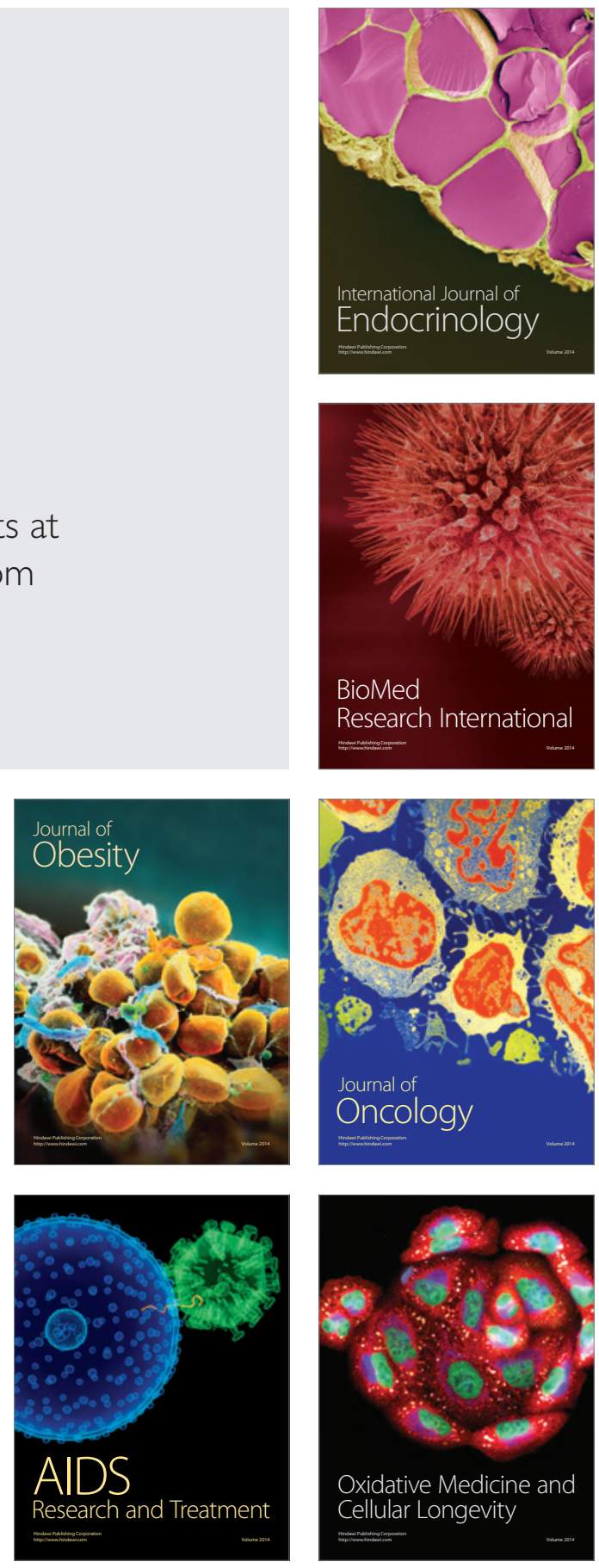